\title{
CELEBRITY ENDORSEMENT IN SOCIAL MEDIA TO ENHANCE BRAND IMAGE \& BRAND LOYALTY
}

\author{
Tyara Citra, Magda Harahap \\ Marketing Communication, London School of Public Relations Jakarta \\ citra.pgp@gmail.com, magda.harahap@gmail.com
}

\begin{abstract}
Today, many companies used social media as their marketing tools, small businesses even use social media as their core platform to market their products or services, as for big companies are using it to create their brand image and directly engage with their audience. Celebrity is also perceived to be more credible and trustworthy to be representing a brand that is specifically matched with the celebrity's image. The first purpose of this paper is to therefore understand the strategy and implementation of using a celebrity endorser through social media activities to enhance brand image and brand loyalty of a fast-moving consumer goods brand. Additionally, this paper is using a comparative approach by comparing in total of ten similar studies conducted to gain insights about celebrity endorsement, social media, brand image and brand loyalty. The paper concludes by discussing the implications of the study based on previous studies and preresearch conducted that can be applied by industrial practitioners to help them achieve their marketing objectives.
\end{abstract}

Keywords: Social media, celebrity endorsement, brand image, brand loyalty 


\section{INTRODUCTION}

As forecasted by Philip Kotler in the coming decade the information economy will penetrate and change almost every aspect of daily life (Kotler, 2001). The consumers are changing in this digital, wireless age, they can connect more easily with other consumers to exchange brand-related information or even create their own marketing messages (Kotler \& Armstrong, 2012, p, 409). Therefore, we can never forget a crucial part in marketing which is branding that has been around for centuries as a means to distinguish the goods of one producer from those of another (Keller, 2013). Further, creating a positive brand image takes marketing programs that link strong, favorable, and unique associations to the brand in memory (Keller, 2013).

Proceed to the higher level where the marketing goal is to move as many customers as possible to "intense" end of range (Duncan, 2005, p. 89). This leads to brand loyalty, main reason why companies are aiming at customer's loyalty has been explained by Duncan that not only are the loyal customers relationships cheaper to maintain, but loyal customers also speak the praises of the brand (2005, p. 89).

Further, in today's generation internet is a big part of life especially for those living in urban areas where everything can be done online and these are not only applied to the young people but also to older ones, those age 35-54 as they are in their productive phase and are easily to adapt to new technology (APJII, 2017). Nowadays, many companies used social media as their marketing tools, small businesses even use social media as their core platform to market their products or services, as for big companies are using it to create their brand image and directly engage with their audience.

This paper is studying a Fast-Moving Consumer Goods (FMCG) brand called Molto, a fabric conditioner brand by Unilever. Therefore, FMCG products have such a short shelflife this either caused by the product's function or usage deteriorates rapidly, such as soaps and detergents, tooth-paste, bathing supplies, cooking ingredients and many others or because high consumer demand since it is daily use products.

Molto has been actively promoting their products through their social media platforms mainly Instagram which is synced to their Facebook page, You-tube and Twitter. These activities allow their audiences or followers to be updated about anything related to the brand such as new product launching or any sponsorship event and promotions. Their most recent campaign is Molto Eau De Parfum using Bunga Citra Lestari as their longterm celebrity endorser of the brand (Molto Indonesia, 2018). The rationale behind using a celebrity endorser is that a famous person can draw attention to a brand and shape the perceptions of the brand based on the knowledge they have about the famous person (Keller, K.L, 2013, p. 278). From 2009 to 2018, Molto was awarded a Top Brand Awards in fabric conditioner category with the top brand index $62.1 \%$ by $2015,62.8 \%$ by 2016 , 
$62.6 \%$ by 2017 , decrease to $50.2 \%$ by 2018 although still becoming the leader among its competitors, such as Downy with the top brand index $29.7 \%$ by $2015,30.5 \%$ by 2016 , $30.7 \%$ by 2017 , and $35.1 \%$ by 2018 . As well as So Klin with the top brand index $7.0 \%$ by $2015,5.8 \%$ by $2016,5.6 \%$ by 2017 , and $5.5 \%$ by 2018 (Top Brand Award, 2018).

According to the data above it is seen that although Molto is still leading in terms of its brand index but there are potentials where it's main competitor Downy, will be getting better in future years. Therefore, this paper focuses on the integrated marketing communication strategy specifically through social media using celebrity endorsement to enhance brand image and brand loyalty of Molto.

\section{LITERATURE REVIEW}

\section{Social Media in an Alternative Communication Model}

According to Cheema and Kaikati (2010), consumers purchase decisions are highly affected by the opinions and decisions of one's peers, where peer to peer communication is acting as a highly valid and reliable source of product information and sharing is a crucial component of the marketing process. Consumers are motivated to spread information via word-of-mouth communications when they are satisfied or dissatisfied with a product (Anderson, 1998) and highly committed to the firm (Dick \& Basu, 1994). On the other hand, social medias are also an alternative channel to build customer relationship management (CRM). The purpose of this study is to provide insight into current best practices for the formation and execution of alternative marketing strategies, to be specific in terms of word of mouth (WOM) marketing strategy, marketing communications, and social media marketing.

\section{Integrated Online Marketing Communication: Implementation and Management}

Due to many advantages of the various online resources, firms need to create strategic thinking to achieve specific and measurable objectives which are consistent with the goals of their marketing communication effort. Internet based marketing platforms allow organizations to implement various communication synergies, therefore all these synergies provide very useful information especially for retail organizations to track the interaction between the online user and their website. Organizations must apply a clear segmentation and positioning strategy, in order to match the needs of every cultural group targeted with their marketing messages. Online users have become more fragmented and proactive, the use of advanced online applications to collect customer data and feedback information is paramount for the success of the online communication campaign (O'Malley and Mitussis, 2002). Organizations must take into account all feedback received from internet audiences this data can be used to modify the online strategy and to better adapt the message to the reaction of the audience. The purpose of this study is to investigate the particularities of integrated marketing communication (IMC) in the online environment. 


\section{Antecedents and outcomes of brand love: the mediating role of brand loyalty}

In the literature, it has been underlined that love relationship, which lasts for years like friendship, consists of many emotional, cognitive, and behavioral experiences (Fournier, 1998). Fournier (1998) claims that feelings of love results in biased positive opinions towards a brand.

Since consumers have become loyal to the brands after having a positive emotional experience with the brand which causes satisfaction, they start to spread their positive experiences to other people in the environment (Dick and Basu, 1994). In the modern market place, consumers purchase products and services not only for their functionalities but also the meanings which they attribute (Levy, 1959). This study concluded that the experience-based factor, concerning brand experience, was found to have an influential effect on brand love, which implies that having an experience with a brand strengthens consumer's emotional feelings towards that brand. Consumers who consider their personality is in a good fit with the brand have stronger feelings towards their love brands. Moreover, the findings show that the passionate emotional attachment with a brand enhances consumer's intention to repurchase and reuse the same products and services. This study also concluded that the more consumers love the brand, the more they deliver positive words to their friends regarding their love brand. It was also supported that loyal customers have a tendency to make positive recommendations about the brand to others. The result of this study also collaborate that brand loyalty enhances the impact of brand love on positive WOM. In other words, customers with a love brand intend to spread more positive words to others, as their loyalty increases.

\section{The Relationship between Integrated Marketing Communication (IMC), Market Orientation (MO), and Brand Orientation (BO)}

According to (Duncan and Mulhern, 2004) IMC is generally considered to be a philosophy or process related to strategically managing all brand messages in a way that contributes to the building of strong brands. In Duncan's representation, IMC is seen as “a process for managing the customer relationships that drive brand value. Duncan explains IMC as "an on-going, interactive, cross-functional process of brand communication planning, execution, and evaluation that integrates all parties in the exchange process in order to maximize mutual satisfaction of each other's wants and needs" (Duncan and Mulhern, 2004 , p. 9). Based on the study we can conclude that fundamental to the success of market orientation is the coordination of effort across

departments to ensure that organizational resources optimally serve to create customer value and the same goes to IMC, where fundamental to the effective IMC is the harmonization of the business's voice in support of the brand (product or corporate). Brand orientation represents the functional or business-unit focus on brands and brand strategies that support strong customer and stakeholder relationships regardless of the brand being at the corporate or product level, or being a service or a manufactured good 
(Bridson and Evans, 2004). Therefore, the link between IMC and brand orientation relies at the fact that the focus of brand orientation is also on creating brand distinctiveness.

\section{Interactive Integrated Marketing Communication: Combining the power of IMC, the new media and database marketing}

According to the study, IMC is a concept of marketing communication planning that recognizes the added value of using a comprehensive plan to evaluate the strategic roles of a variety of communication disciplines and combine these disciplines to provide clarity, consistency, and maximum communication impact (Schultz et al, 1993). According to the study there are four elements that are central to the use of interactive media in IMC process: (1) the two-way nature of the communication system, (2) the level of response control each party has in the communication process, (3) the personalization of the communication relationship, and (4) the use and involvement of database technology. Once the interactive IMC strategy has been developed, segment- specific IMC plans can be formulated. This study concluded the unique characteristics of the new media requires that a database-driven segmentation approach to communication strategy be employed. This should include the development of a customized, interactive, integrated marketing communication plan as well. However, an integrated IMC plan should not be considered an end goal but rather a starting point in the development and implementation of a 'smart' marketing program.

\section{Validating a model to measure the Brand Loyalty of Fast Moving Consumer Goods (FMCG)}

According to the study the concept of brand loyalty first appeared as a uni-dimensional construct. Two separate loyalty concepts then evolved, one to measure attitude and one to measure behavior in the1950s. Brand loyalty is built over time through a collection of positive experiences that requires consistent effort and attention to detail. Loyal customers are repeat customers who choose a brand or company without even considering other options. They buy more, and they buy more regularly, and they frequently recommend the brand to others (Manternach, 2010, p. 28). Aaker (1991, p. 43) has formerly noted that different methods of measuring brand loyalty exist that are based upon the actual purchasing behavior of the consumer, or upon the loyalty constructs or influences of switching costs, satisfaction and commitment. If brand loyalty is properly managed, it represents a strategic asset for the company and can be used in several ways to provide a certain value for the company (Aaker 1991, p. 43). Therefore, the objective of this study is to validate a model to measure brand loyalty in FMCG industry, therefore the elements are customer satisfaction, brand trust, relationship pro-ness, involvement, commitment, brand affect, brand relevance, brand performance, and culture which have been proven in the study if these elements are indeed a construct to validate brand loyalty. 


\section{Effects of Celebrity-organization congruence on audience attitudes, preferences, and credibility ratings for goodwill ambassadors}

In advertising, a celebrity is defined as 'an individual who is known to the public (i.e., actor, sports figure, entertainer, etc.) for his or her achievements in areas other than that of the product class endorsed' (Friedman \& Friedman, 1979; Kamins, Brand, Hoeke, \& Moe, 1989). The term 'celebrity endorsement' is used to refer to the effect generated by the use of a celebrity in advertising. These endorsements may have celebrities giving expert opinions, serving as a spokesperson for a product, or simply being associated with it (McCracken, 1989). According to the study during the meaning transfer process, what is transferred is the image of the celebrity. If the celebrity is considered to represent a form of brand, the image that is transferred can be viewed as the celebrity's brand image. Brand image is defined as consumer's perceptions of a brand as reflected by the brand associations held in consumer's memory (Keller, 1998, p. 49). According to the study, an image formed from a set of associations can be transferred when two entities are linked in some context. Therefore, this study concluded that a high congruence situation in a celebrity endorsement can be expected to lead to a positive reverse transfer effect on the audience's image of the celebrity, while a low congruence situation can be expected to result in a negative effect. Although many companies and organizations have traditionally made use of a celebrity's recognition and reputation in marketing their products and services, audience perceptions of the celebrity him or herself can be adversely affected when the celebrity and the product are viewed as being low in congruence.

\section{Flying with Nicole Kidman or Jennifer Anniston? Brand funnel stages' influence on brand personality}

This study focuses on the visual perception of global advertising video campaigns of two United Arab Emirates (UAE) based airline companies, Etihad Airways and Emirates. Etihad Airlines and Emirates launched campaigns in the same year (2015) using female celebrities that serve as brand ambassadors and opted for a strategy of catering to luxury, high-end travelers. On March 14 2015, Etihad Airlines launched its new global brand campaign "Flying Re-Imagined" with a new television commercial using Nicole Kidman, an Academy award-winning Australian actress, as both star and narrator of the feature. The airline's chief commercial officer said: "Nicole Kidman embodies worldly sophistication, intelligence, originality, and elegance - values which form the foundations of the Etihad brand" (Etihad Airways, 2016). On October 5 2015, Emirates launched its television commercial, "Wake up to flying as it should be", featuring Hollywood star Jennifer Aniston. The airline's Senior Vice President (SVP) for corporate communications, marketing, and brand mentioned that Jennifer Aniston's appeal and effortless connection with a global audience makes her the perfect choice for their campaign (McQueen, 2015). According to the study, celebrities are perceived as more credible than non- celebrity endorsers, with their high profile and wide recognition exerting a greater influence on consumer's brand attitudes and purchase intention, and even though they share some common characteristics, including recognition, status, and popularity, each celebrity embodies his or her own unique image in the media (Choi \& Rifon, 2007). Result of this 
study concluded that Emirates incorporation of Jennifer Aniston seemed to create a more masculine and trendy personality, while Etihad Airlines use of Nicole Kidman is seen as having a more feminine and classy personality. Since Etihad Airlines' TVC trying to convince higher-demand travelers, the result in brand personality was expected. On the other hand, Emirates used a more comedic fan- based TVC, which resulted in a trendier brand. Based on this result in order to increase consideration, Etihad Airlines should work more on a family-oriented image and a confident brand. Since based on this study's findings indicate that tourists are more loyal to an airline and recommend it when it is seen to be more family-oriented than individualistic.

\section{Celebrity ambassador / celebrity endorsement: takes a licking but keeps on ticking}

The study explains that in the case of expensive wristwatches, the consumer's personality and extent to which they see products as extensions of themselves and view products as personalities are important points to consider. According to Sirgy (1986) the importance of self-concept theory in consumer behavior research by explaining that consumers who perceive the product image to be consistent with their actual self-concept are likely to feel motivated to purchase and consume that product. It would appear that possessions can be used to satisfy psychological needs, such as actively creating one's self-concept, reinforcing and expressing self-identity, and allowing self-differentiation and to assert individuality (e.g. Ball \& Tasaki, 1992; Kleine, Schultz, Kleine, \& Allen, 1995). The study concluded that the likelihood of an endorsement being effective will be increased by the consumer's belief in the credibility of celebrity ability to endorse the brand, the strength of liking for the celebrity and consumers own perceptions of how the brand may enhance their own self-image. As well as the importance to match the values of the celebrity with the brand values or getting the right celebrity to endorse the right brand. In this way, consumers perceive the brand as having superior quality because it has been endorsed by a credible source. However, just as important is the message being delivered and the credibility of the message deliverer (the celebrity) in delivering the message content.

\section{Advertising strategies for brand image repair: the effectiveness of advertising alliances}

As cited from the study brand images contain the building blocks of expectations, which helps explain why brand image enhancement is a major task for brand managers (Keller 1993 , 2008). Image enhancement is a continuous effort because images are dynamic and change over time as a result of both external factors, such as the communication for competitor's brands, and internal changes, such as in the marketing mix. Keller (1993) also defines brand image as the set of brand associations linked directly or indirectly to a brand name in long-term memory. He suggests that brand images typically consist of three broad categories of brand associations: attitudes, benefits, and attributes. Brand benefits are particularly important because they contain information on the expected utility of using brands and thus influence attitudes and preferences. According to Keller (1993), there are three types of brand benefits: functional, experiential, and symbolic. Functional benefits represent the problem-solving capacity of the brand, experiential 
benefits refer to sensory pleasure (e.g. taste, feeling of comfort) or cognitive stimulation (e.g. learning, fantasies) derived from brand usage.

Symbolic benefits represent psychological and social signals about the brand user, enhancing his or her self-concept and providing desired social classifications (Escalas and Bettman 2005; Swaminathan, Page, and Gürgan-Canli 2007). The study focuses on brand personality and compares the ability of advertising alliances and traditional advertising to strengthen positive traits and downplay negative traits for a real brand in need of image repair. The results of this study show that the advertising alliance is considerably more effective in upgrading positive brand personality traits than single-brand advertising.

\section{METHOD}

In today's generation internet is a big part of life especially for those living in urban areas where everything can be done online and these are not only applied to the young people but also to older ones, those age 35-54 as they are in their productive phase and are easily to adapt to new technology (APJII, 2017). According to Asosiasi Penyelenggara Jasa Internet Indonesia (APJII), out of 262 million total population in Indonesia, more than $50 \%$ which is around 143 million people dominated by those age 13-18 years old are active internet users per 2017. These people are actively using internet with vary needs such as communicating, buying and ordering products or services to starting business and creating creative contents. These facts lead companies to use social media as their marketing platforms.

\section{Social Media}

According to Sweeeny \& Craig, social media is a technology type where the media is designed to be easily shared. In addition, "Social media" is an umbrella term that covers technology such as blogs, vlogs, photo sharing, video sharing, wikis, podcasts, microblogs, music sharing, forums, rating and reviews, social bookmarks, and online communities, to name a few (2011, p. 16). Sweeney \& Craig (2011) explained that social media has changed the way we do business online. In this highly competitive marketplace, businesses are doing everything they can to get in front of their target customer, differentiate themselves from the competition, connect and engage customers and potential customers, get their brand recognized, and sell their products and services (Sweeny \& Craig, 2011, p. 15). Therefore, social media and social networking provide us with many opportunities to achieve these objectives.

\section{Celebrity Endorsement}

From the book Strategic Brand Management, according to (Keller, K.L, 2013, p. 278-282) celebrity endorsement is, using well-known and admired people to promote products. The rationale behind these strategies is that a famous person can draw attention to a brand and shape the perceptions of the brand, by virtue of the inferences that consumers 
make based on the knowledge they have about the famous person. The hope is that the celebrities' fans will also become fans of their products or services. A celebrity endorser should have a high level of visibility and a rich set of potentially useful associations, judgments, and feelings. Ideally, he or she would be credible in terms of expertise, trustworthiness, and likability or attractiveness, as well as having specific associations that carry potential product relevance. Marketers should choose a wellknown and well-defined celebrity whose associations are relevant to the brand and likely to be transferable. Then, there must be a logical fit between the brand and the person. Third, the advertising and communication program should use the celebrity in a creative fashion that highlights the relevant associations and encourages their transfer. According to McCracken in Chris Fill (2013, p. 59) celebrity endorsement works through the theory of meaning transfer. Consumers make an overall assessment of what a celebrity 'represents' to them, based on their perception and interpretation of the celebrity's identity cues. These cues relate to their behavior, comments, ability, and attributes that are of particular interest to the consumer (Fill, C., 2013, p. 59).

Rossiter \& Percy in an article journal by Rossiter himself (2012) mentioned a model called VisCAP model which explains about endorser's characteristics, which are:

- Visibility: an endorser must be widely well-known and creatable via advertising for "real people" presenters or animated characters (Rossiter, 2012).

- Credibility: an endorser must be an expertise in his/her field and able to maintain trustworthiness (Rossiter, 2012).

- Attraction: an endorser must possess likability and a role model identification (Rossiter, 2012).

- Power: an endorser must possess coercive persuasion (Rossiter, 2012).

Thus, five specific present characteristics above are relevant for advertising: visibility or well-known, expertise, trustworthiness, likeability, and role model identification (Rossiter, 2012).

\section{Brand Image}

According to Duncan in his book Principles of Advertising \& IMC (2005, p.82), brand image is an impression created by brand messages and experiences and assimilated into a perception or impression of the brand, an image makes a statement about a brand's personality, it also adds value to a brand because the image can communicate something about the buyer to other people. Therefore, an identity and a position is not enough to make the brand come alive and connect with customers...an image makes a statement about a brand's personality (Duncan, 2005, p. 82). Brand image is defined as consumer's perceptions of a brand as reflected by the brand associations held in consumer's memory according to Keller (1998) cited from the article journal by Jae-woong Yoo \& Young-ju Jin (2013).

Creating a positive brand image takes marketing programs that link strong, favorable, and unique associations to the brand in memory (Keller, K.L, 2013, p. 77). Brand 
associations may be either brand attributes or benefits (2013, p. 77). Brand attributes are those descriptive features that characterize a product or service $(2013$, p. 77). Brand benefits are the personal value and meaning that consumers attach to the product or service attributes (Keller, K.L, 2013, p. 278-282). Further into the topic, unique associations help consumers choose the brand. Therefore, some factors in general affect the strength, favorability, and uniqueness and brand associations (p. 77):

- Strength of Brand Associations: The more deeply a person thinks about product information and relates it to existing brand knowledge (p. 78). The stronger the resulting brand associations be (2013, p. 78). Direct experiences create the strongest brand attribute and brand associations and are particularly influential in consumers decisions when they accurately interpret them (Keller, K.L, 2013, p. 78).

- Favorability of Brand Associations: Consumers convinced that the brand possesses relevant attributes and benefits that satisfy their needs and wants (Keller, K.L, 2013, p. 78).

- Uniqueness of Brand Associations: A sustainable competitive advantage or "unique selling proposition" that gives consumers a compelling reason why they should buy it (Keller, K.L, 2013, p. 78).

\section{Brand Loyalty}

Brand loyalty is the degree of attachment that customers have to a brand as expressed by repeat purchases, helps companies customize brand messages (Duncan, 2005, p. 89). Customers with brand loyalty have strong emotional feelings for some brands but see other brands as utilitarian (p. 89). Assume that brand relationships vary from "no loyalty" to "intense loyalty", customers at the "no loyalty" are brand switchers and those at the "intense loyalty" end consistently buy a particular brand (Duncan, 2005, p. 89). It is a marketing goal to move as many customers as possible to the "intense" end of the range (p. 89). Reason to this are not only the royal customers relationships are cheaper to maintain, but loyal customers also speak the praises of the brand, making positive contributions to the brand's marketing communication efforts (2005, p. 89).

Keller (2013, p. 107) mentioned a model called brand resonance model, which describes how to create intense, active, loyalty relationships with customers. The model considers how brand positioning affect what consumers think, feel, and do and the degree to which they resonate or connect with a brand (Keller, K.L, 2013, p. 107). He mentioned a model called brand resonance as the final step of the ultimate relationship and level of identification that customer has with the brand $(2013$, p. 120). Therefore, brand resonance can be break down into four categories:

- Behavioral loyalty: According to Keller it can be measured based on repeat purchase and the amount or share of category volume attributed to the brand in other words how often do customers purchase a brand and how much do they purchase? (Keller, K.L, 2013, p. 120). 
- Attitudinal attachment: some customers may buy out of necessity therefore, customers should go beyond having a positive attitude to viewing the brand as something special in a broader context (Keller, K.L, 2013, p. 120). He added that creating greater loyalty requires creating greater attitudinal attachment, through marketing programs and products and services that fully satisfy consumer needs (Keller, K.L, 2013, p. 120).

- Sense of community: a situation when customers feel a kinship or affiliation with other people associated with the brand, whether fellow brand users, or employees or Representative of the company (Keller, K.L, 2013, p. 121).

- Active engagement: according to Keller, perhaps the strongest affirmation of brand loyalty occurs when customers are engaged, or willing to invest time, energy, money, or other resources in the brand beyond those expended during purchase or consumption of the brand (Keller, K.L, 2013, p. 121). Such as choosing to visit brand-related websites, participate in chat rooms, or post to discussions (2013, p. 121).

Further into the topic Keller explained that in short, these four categories have two dimensions: intensity and activity. Intensity measures the strength of the attitudinal attachment and sense of community (Keller, K.L, 2013, p. 122). While activity tells us how frequently the consumer buys and uses the brand, as well as engages in other activities not related to purchase or consumption (2013, p. 122).

\section{RESULTS AND DISCUSSION}

Throughout the comparative studies, it has been understood that to create a successful IMC program all components of a marketing communications campaign must feed into and reinforce one another, and communicate to consumers the same consistent-message. It is related to the creation of brand image in terms of choosing celebrity endorser to represent a brand, there are many factors to be considered in order to decide whether the star fits the brand or not, such as consumer's belief in the credibility of celebrity ability to endorse the brand, the strength of liking for the celebrity and consumers own perceptions of how the brand may enhance their own self-image. This leads to customer's brand loyalty which can be measured from customer satisfaction towards the brand, brand trust, brand relevance as well as brand performance specifically for an FMCG brand. When consumers start to consider their personality is in a good fit with the brand, they would have stronger feelings towards the brand, therefore it is crucial to be selective in choosing celebrity endorser that represents the taste, value, and preferences with the brand's target market in order to create a successful celebrity endorsement in an overall IMC strategy specifically to enhance brand image that would lead to brand loyalty. According to the studies compared above the use of social media platforms are indeed supporting the strategy of alternative marketing communications in a way to reinforce and promote the same brand message at all consumer touch points. This study will provide both marketers and academics with a clear understanding about the relation and 
importance within choosing a celebrity endorser to the brand's image and goal to create brand loyalty in order to create an effective IMC strategy especially for an FMCG brand. Loyal customers are more likely to make positive recommendations about the brand, that would have the substantial impact on the buying decision process of other consumers.

\section{CONCLUSION}

Taking into consideration our final conclusion, it can be suggested that there are other unmentioned factors that would play important roles as a result of celebrity endorsement within IMC strategy, such as consumer's decision on using or purchasing the brand because of the use of that specific celebrity endorser. Future research should be attempted to understand how this relations in general could be combined to be used for other industy besides FMCG as well as the process of customer decision making upon the use of celebrity endorser.

\section{REFERENCES}

Bicakcioglu, N., Ipek, I., \& Bayraktaroglu, G. (2016). Antecedents and outcomes of brand love: The mediating role of brand loyalty. Journal of Marketing Communications. doi: $10.1080 / 13527266.2016 .1244108$

Bohang, F.K. (2018, February 22). Berapa Jumlah Pengguna Internet Indonesia?. Kompas.com. Retrieved from https://tekno.kompas.com

Castronovo, C., \& Huang, Lei. (2012). Social media in an alternative marketing communication model. Journal of Marketing Development and Competitiveness, 6(1), 119-124.

Duncan, T. (2005). Principles of Advertising \& IMC (2nd ed.). New York: The McGraw Hill.

Fill, C. (2013). Marketing Communications: Brands, experiences and participation (6th ed.). Harlow: Pearson Education Limited.

Gurau, C. (2008). Integrated online marketing communication: Implementation and management. Journal of Communication Management, 12(2), 169-184. doi: $10.1108 / 13632540810881974$

Keller, K. L. (2013). Strategic Brand Management: Building, Measuring, and Managing Brand Equity (4th ed.). Harlow: Pearson.

Kotler, P. (2001). Kotler on marketing: How to create, win, and dominate markets. London, UK: Simon \& Schuster.

Kotler, P., \& Armstrong, G. (2012). Principles of Marketing. (14th ed.). New Jersey: Prentice Hall. 
Kotsi, F., \& Valek, N.S. (2017). Flying with Nicole Kidman or Jennifer Anniston? Brand funnel stages' influence on brand personality. Journal of Travel \& Tourism Marketing. doi: 10.1080/10548408.2017.1360232

Maehle, N., \& Supphellen, M. (2013). Advertising strategies for brand image repair: The effectiveness of advertising alliances. Journal of Marketing Communications. doi: 10.1080/13527266.2013.866594

Molto Indonesia. 2018. "Molto Inspirasi Keharuman." Accessed on May 2018. http://www.molto.co.id/artikel/kategori/1088640/keharuman-dan-anda.

Moola, A.I., \& Bisschoff, C.A. (2012). Validating a model to measure the brand loyalty of fast moving consumer goods. Journal of Social Sciences, 31(2), 101-115. doi: 10.1080/09718923.2012.11893019

Peltier, J.W., Schibrowsky, J.A., \& Schultz, D.E. (2015). Interactive integrated marketing communication: Combining the power of IMC, the new media and database marketing. International Journal of Advertising, 22(1), 93-115. doi: 10.1080/02650487.2003.11072841

Proctor, T., \& Kitchen, P.J. (2018). Celebrity ambassador/celebrity endorsement takes a licking but keeps on ticking. Journal of Strategic Marketing. doi: 10.1080/0965254X.2018.1430059

Reid, M., Luxton, S., \& Mavondo, F. (2013). The relationship between integrated marketing communication, market orientation, and brand orientation. Journal of Advertising, 34(4), 11-23. doi: 10.1080/00913367.2005.10639210

Rossiter, J. R., \& Smidts, A. (2012). Print advertising: Celebrity presenters. Journal of Business Research, 65, 874-879.

Sweeny, S., \& Craig, R. (2011). Social Media for Business: 10 Ways to Grow Your Business Without Wasting Your Time. Canada: Maximum Press.

Top Brand Award. 2018. "Kategori: Produk Rumah Tangga." Accessed on February 2018. http://www.topbrand-award.com/top-brand-survey/survey result/top_brand_index_2018_fase_1

Yoo, J.W., \& Jin, Y.J. (2013). Effects of celebrity organization congruence on audience attitudes, preferences, and credibility ratings for goodwill ambassadors. Asian Journal of Communication, 23(6), 620-636. doi: 10.1080/01292986.2013.790912 
CELEBRITY ENDORSEMENT IN SOCIAL MEDIA TO

ENHANCE BRAND IMAGE \& BRAND LOYALTY

Tyara Citra, Magda Harahap 